JURNAL ILMIAH ELEKTRONIKA DAN KOMPUTER, Vol.13, No.1, Juli 2020, pp. 1 - 7

p-ISSN : 1907-0012 (print)

e-ISSN : 2714-5417 (online)

http://journal.stekom.ac.id/index.php/elkom

- page 1

\title{
Analisis Legalitas Tanah Wakaf Muhammadiyah Jawa Tengah dengan menggunakan Algoritma ID3
}

\section{Muhammad Munsarif S.Kom,M.Kom}

Universitas Muhammadiyah Semarang

Jl.Kedungmundu No 18 Semarang, telp/fax 024 76740296, e-mail: m.munsarif@unimus.ac.id

\begin{tabular}{|c|c|}
\hline ARTICLE INFO & ABSTRACT \\
\hline $\begin{array}{l}\text { Article history: } \\
\text { Received } 30 \text { Maret } 2020 \\
\text { Received in revised form } 2 \text { April } 2020 \\
\text { Accepted } 10 \text { April } 2020 \\
\text { Available online } 17 \text { April } 2020\end{array}$ & $\begin{array}{l}\text { Waqf information system In April } 2020 \text { shows the } \\
\text { number of waqf land in Indonesia has an area of } \\
51,259.84 \text { Ha. More waqf received in the form of } \\
\text { land creates a problem of disputes and disputes that } \\
\text { lead to legal cases Muhammadiyah is the second- } \\
\text { largest Islamic organization that has assets in the } \\
\text { form of waqf land that has not been able to resolve } \\
\text { existing problems. In this study, an analysis of legal } \\
\text { potential and waqf land disputes is used using ID3 } \\
\text { Algorithm to classify potential land disputes based } \\
\text { on the status of the land deed, owner's name, } \\
\text { location of waqf and its use so that it can produce } \\
\text { data on the ownership rights of waqf land which has } \\
\text { the potential for legal disputes and no legal disputes. } \\
\text { research shows that potential legal problems are still } \\
\text { present. The ID3 algorithm is able to produce } \\
\text { information as a basis for reducing disputes and the } \\
\text { loss of waqf land. }\end{array}$ \\
\hline
\end{tabular}

Keywords: ID3 Algorithm, Waqf information system, Muhammadiyah asset information system

\section{Introduction}

Wakaf tanah[1] merupakah salah satu ibadah yang sangat di minati oleh umat islam di Indonesia.Berdasarkan data dari sistem informasi wakaf April 2020 ( siwak.kemenag.go.id) Jumlah tanah wakaf indonesia mencapai 51.259,89 Ha.Dalam rangka mengatur pengelolaan wakaf, pemerintah indonesia indonesia telah membuat Undang undang No 41 tahun 2004 dan di perkuat dengan peraturan pemerintah Nomor 42 tahun 2006 dan di perkuat denan pengaturan pelaksanaan pada tahun 2018 melalui PP No 25 tahun 2018.Banyaknya permasalahn tanah wakaf di indonesia dikarenakan banyak tanah wakaf yang tidak tertib secara administrasi .Hal ini menyebabkan kasus legalitas tanah wakaf yang tidak di perhatikan pada saat serah terima wakaf ataupun setelahnya,Sehingga banyak kasus yang terjadi antara ahli waris pewakaf yang menuntut hak atas tanah tersebut di kemudian hari.Pengelolaan wakaf yang buruk berpotensi menimbulkan banyak konflik yang berujung di pengadilan,sehingga perlu solusi dan penyelesaian secara tuntas. Salah satu Upaya untuk mencari solusi atas persoalan wakaf tanah yang di lakukan oleh Pemerintah Indonesia adalah dengan membuat organisasi yang bernama BWI ( Badan Wakaf Indonesia),namun sampai sekarang belum mampu memberikan solusi atas masalah yang ada

Muhammadiyah [2]sebagai salah satu organisasi islam terbesar di Indonesia yang memiliki banyak tanah wakaf mempunyai kepentingan untuk menyelamatkan semua aset yang 
berupa tanah wakaf. Majelis wakaf di bentuk untuk mengatur, mengelola data dan pemanfaatan kehartabendaan milik Muhammadiyah. Pengelolaan wakaf yang baik[3] dan profesional akan mampu memberikan manfaat yang lebih luas kepada masayarakat untuk kegiatan ekonomi dan perdagangan yang lebih luas di bidang Kesehatan,Dakwah dan pendidikan. Ketiga amal usaha tersebut merupakan unggulan untuk pemanfaatan tanah wakaf yang dikelola oleh Muhammadiyah.

Majelis wakaf Muhammadiyah Jawa Tengah telah membuat Sistem informasi Aset wakaf dan kehartabendaan untuk mendata selutuh aset wakaf yang dimiliki .Berdasarakan data tersebut (SIMAM 2020), Sistem informasi tersebut hanya mampu melihat pemanfaatan tanah berdasarakan penggunaan dan pemanfaatannya saja dan belum mampu melihat potensi masalah hukum yang akan terjadi,sehingga dibutuhkan sistem informasi yang mempu memberikan data yang mampu menunjukkan permasalahan legalitas tanah dan kasus hukum yang sedang terjadi maupun yang berpotensi terjadi di kemudian hari.

Pemanfaatan Sistem Informasi yang tepat untuk memecahkan masalah tersebut di atas dengan tekhnik data mining[4] untuk membuat pengelompokan data, membuat prediksi, membuat estimasi, menentukan kaidah asosiasi data yang ada. Untuk memecahkan masalah yang ada diperlukan pemilihan metode data mining yang tepat untuk menggambarkan masalah dan solusi yang tepat.Dari beberapa metode data mining yang ada peneliti memilih menerapakan algoritma klasifikasi data mining induksi Decission Tree (ID3) dalam rangka menentukan status kepemilikan tanah wakaf yang berpotensi konflik dan Tanah wakaf yang tidak memiliki potensi kasus hukum atau konflik sebagai dasar untuk membuat program kerja di bidang hukum majelis wakaf Muhammadiyah . Algoritma ID3[5] juga akan mampu memberikan diagram keputusan atau Decision Tree (pohon keputusan) secara rinci dan mudah di pahami.

Metode klasifikasi data mining algoritma ID3 akan digunakan dalam memecahkan masalah kasus hukum di bidang wakaf dengan membuat analisa tentang prediksi kategori berdasarkan status kepemilikan tanah akan di gunakan dalam penelitian ini.

\section{Metodologi Penelitian}

Metodologi meliputi empat tahap adalah Tahap pengumpulan data,Tahap pembersihan data,Tahap transformasi data,Tahap pembentukan pohon keputusan dan dokumentasi.

\subsection{Pengumpulan Data}

Tahap pengumpulan data menggunakan Metode pengamatan secara langsung yaitu menggunakan menggunakan data sekunder dari 35 Pimpinan Daerah Muhamadiyah Jawa Tengah di bidang Majelis wakaf Jawa Tengah.Peneliti menggunakan data dari semua majelis wakaf yang sudah di masukkan ke apliaksi Sistem informasi aset Muhammadiyah wilayah Jawa Tengah.

\subsection{Pembersihan Data}

Pada Tahapan ini akan melakukan proses pembersihan data dengan cara mengelompokan dan menyederhanakan menjadi data yang lebih berguna. Berikut ini adalah beberapa variable dan atribut untuk proses pembersihan data :

- Pada Atribut kepemilikan yang ditranformasikan menjadi 'Hak milik,HGU,Hibah,Akta Wakaf,Akta Jual Beli,Letter D,HGB dan No Document

- Pada Atribut untuk Pemilik Sekarang akan ditransformasikan'PP Muhammadiyah dan Pribadi

- Pada Atribut status tanah yang ditransformasikan 'Tegalan ,Pekarangan, dan Tanah kosong

- Pada tahap pembersiahan di Atribut penggunaan yang ditranformasikan menjadi 'Kesehatan, Perkantoran,religi, kosong dan Pendidikan 
- Penentuan label Kategory adalah nilai Keluaran yang akan dijadikan sebagai target atau goal dengan memberikan nilai 'Potensi Masalah' atau 'Tidak ada Masalah'.

Dalam tahapan ini hanya atribut-atribut yang dianggap penting saja yang akan digunakan, maka harus dilakukan proses pembersihan data yang benar.Dimana Pada proses pemerikasaan data, penghilangan redudansi data,perbaikan kesalahan data dan menghapus data yang tidak dibutuhkan sehingga akan menghasilkan data yang penting dan bisa digunakan untuk tahapan atau proses selanjutnya.

\subsection{Tahap Transformasi Data}

Tahap meliputi tahap Penyederhanaan dan prosen mengelompokan data yang di bagi ke dalam variable input dan variable output.

\subsection{Tahap Pembentukan Pohon Keputusan}

Algoritma ID3 akan di gunakan pada Tahapan ini dengan Pemodelan pembuatan pohon keputusan .

\subsection{Tahap Dokumentasi}

Pada tahap Dokumentasi mengunakan software RapidMiner guna melakukan pengolahan data Wakaf yang telah diteliti guna memperoleh pohon keputusan secara tepat.

\section{Hasil and Pembahasan}

\section{a.Tahap Pengumpulan Data}

Peneliti meggunakan data yang di peroleh dari Majelis wakaf yang berada di setiap level yang meliputi seluruh desa, kecamatan dan seluruh kota di wilayah jawa tengah uang berdada di bawah majelis wakaf muhammadiyah jawa tengah, Semua data di masukkan ke dalam sistem informasi aset muhammadiyah secara online. Data tersebut digunakan untuk sample dan dipakai sebagai data uji yang terdiri dari banyak atribut, seperti Kode Wilayah,Kode Aset,No Sertifikat,Jenis Sertifikat,Status Tanah,Pemilik ,Alamat,Luas,cara perolehan,harga perolehan,tanggal perolehan,Penggunaan,Kategori,Bidang,Lokasi,Arsip di simpan,Fasum,NIB

\section{b.Tahap pembersihan Data}

Data yang masih terdiri dari banyak atribut kemudian dilakukan pembersihan dengan cara mengahap.us atribut yang tidak di butuhkan dengan tujuan untuk mmebuat klasifikasi untuk menentukan database yang berkwalitas atau yang lebih berguna.

\section{c.Tahap transformasi data}

Brikut ini adalah Data tabel dari Hasil yang diperoleh pada tahap pengumpulan data, tahap pembersihan data ,tahap transformasi data. 
3.1 Table Hasil Pengumpulan, Pembersihan dan Transformasi Data

\begin{tabular}{|l|l|l|l|l|}
\hline KEPEMILIKAN & STATUS TANAH & PEMILIK SEKARANG & PENGGUNAAN & POTENSI MASALAH \\
\hline Hak Milik & Pekarangan & PP Muhammadiyah & Pendidikan & Tidak ada \\
\hline Hak Milik & Pekarangan & PP Muhammadiyah & Pendidikan & Tidak ada \\
\hline Hak Milik & Pekarangan & PP Muhammadiyah & Pendidikan & Tidak ada \\
\hline Hak Milik & Pekarangan & PP Muhammadiyah & Sosial & Tidak ada \\
\hline Akta Jual Beli & Pekarangan & PP Muhammadiyah & Pendidikan & Tidak ada \\
\hline Akta Jual Beli & Pekarangan & PP Muhammadiyah & Pendidikan & Potensi Masalah \\
\hline Hak Milik & Pekarangan & PP Muhammadiyah & Pendidikan & Potensi Masalah \\
\hline Akta Jual Beli & Pekarangan & PP Muhammadiyah & Pendidikan & Potensi Masalah \\
\hline Hak Milik & Pekarangan & Pribadi & Pendidikan & Potensi Masalah \\
\hline Hak Milik & Pekarangan & PP Muhammadiyah & Ibadah & Tidak ada \\
\hline Hak Milik & Pekarangan & PP Muhammadiyah & Tanah Kosong & Tidak ada \\
\hline Hak Milik & Pekarangan & PP Muhammadiyah & Pendidikan & Tidak ada \\
\hline Hak Milik & Pekarangan & PP Muhammadiyah & Pendidikan & Tidak ada \\
\hline Hak Milik & Pekarangan & PP Muhammadiyah & Pendidikan & Potensi Masalah \\
\hline Hak Pakai & Pekarangan & PP Muhammadiyah & Ibadah & Potensi Masalah \\
\hline Hak Milik & Pekarangan & Pribadi & Tanah Kosong & Potensi Masalah \\
\hline Hak Milik & Pekarangan & PP Muhammadiyah & Pendidikan & Tidak ada \\
\hline
\end{tabular}

Sumber : Majelis Wakaf Jawa Tengah 2020 ( Sistem informasi aset Muahmmadiyah)

\subsection{Pohon Keputusan dengan Model Algoritma ID3}

Dalam proses pembuatan pohon keputusan menggunakan model Algoritma ID3[6] dengan menggunakan Software RapidMinner Studio .Pada tahap ini akan menghasilkan Permodelan Pohon keputusan yang sangat berguna untuk memberikan gambaran yang mudah untuk membuat keputusan. Berdasarkan Pohon keputusan dengan menggunakan atribut kategori kepemilikan di peroleh informasi sebagai berikut:

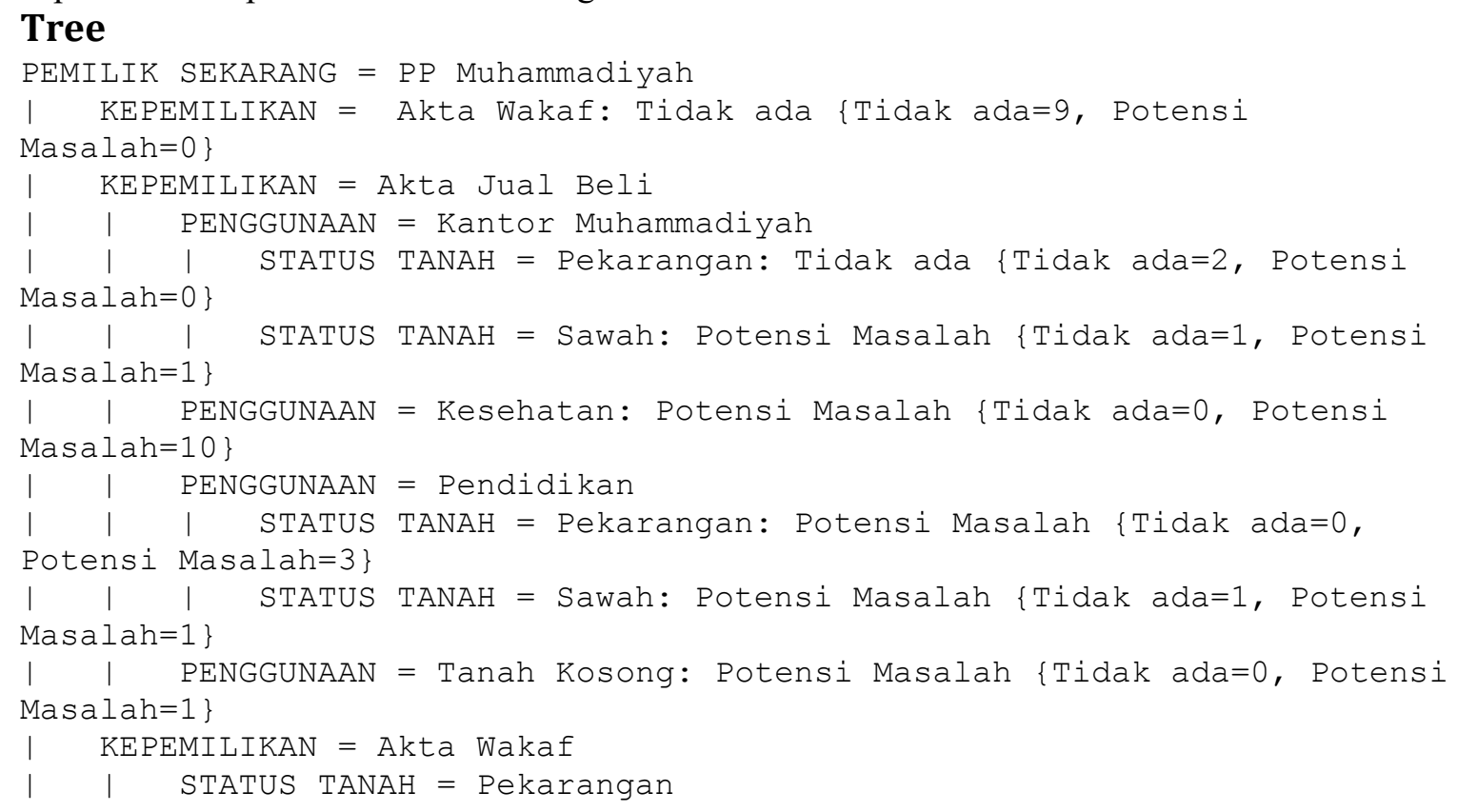

JURNAL ILMIAH ELEKTRONIKA DAN KOMPUTER Vol. 13, No. 1, Juli $2020: 1$ - 7 


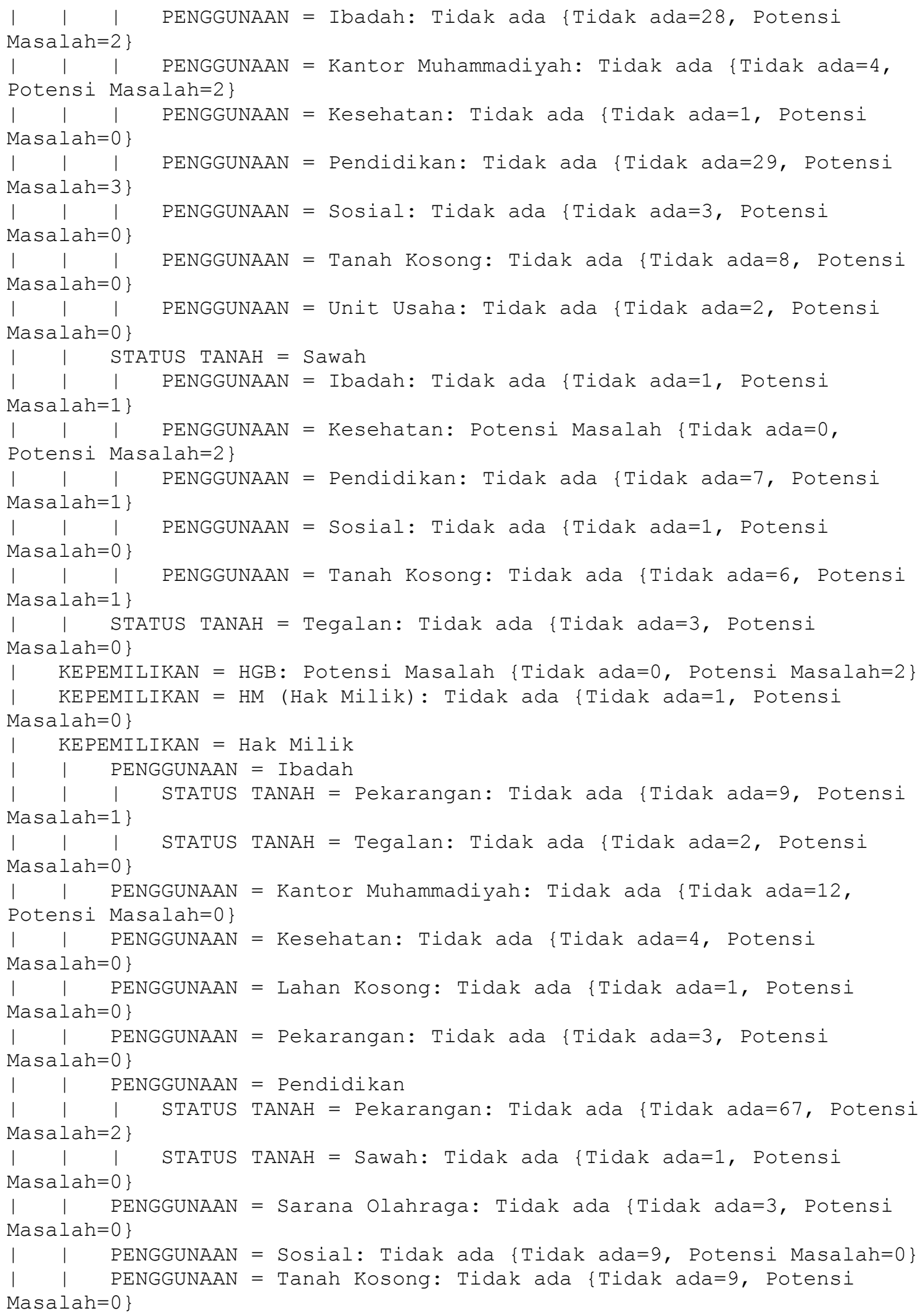


I $\quad$ PENGGUNAAN = Unit Usaha: Tidak ada $\{$ Tidak ada=5, Potensi Masalah=0

I $\quad$ KEPEMILIKAN = Hak Pakai: Potensi Masalah $\{$ Tidak ada=0, Potensi Masalah=2

KEPEMILIKAN $=$ Hibah: Tidak ada $\{$ Tidak ada=8, Potensi Masalah=0 $\}$
KEPEMILIKAN $=$ Letter D: Potensi Masalah $\{$ Tidak ada=0, Potensi

Masalah=5

I $\quad$ KEPEMILIKAN = No Document: Potensi Masalah $\{$ Tidak ada=0, Potensi

Masalah=1\}

PEMILIK SEKARANG = Pribadi

I $\quad$ KEPEMILIKAN $=$ Akta Wakaf

I $\quad$ PENGGUNAAN = Pendidikan: Tidak ada $\{$ Tidak ada=1, Potensi Masalah $=0\}$

| $\mid$ PENGGUNAAN = Sosial: Potensi Masalah $\{$ Tidak ada=0, Potensi Masalah=1\}

I $\quad$ KEPEMILIKAN = AJB (Akta Jual Beli): Potensi Masalah $\{$ Tidak ada=0, Potensi Masalah=1\}

I $\quad$ KEPEMILIKAN = Akta Jual Beli: Potensi Masalah $\{$ Tidak ada=0, Potensi Masalah=3

I $\quad$ KEPEMILIKAN = Akta Wakaf: Potensi Masalah $\{$ Tidak ada=0, Potensi Masalah=22\}

I KEPEMILIKAN = HGB: Potensi Masalah $\{$ Tidak ada=0, Potensi Masalah=2 $\}$

I KEPEMILIKAN = HGU: Potensi Masalah $\{$ Tidak ada=0, Potensi Masalah=1 $\}$

| KEPEMILIKAN = Hak Milik

$\mid \quad$ PENGGUNAAN = Ibadah

| $\mid$ | STATUS TANAH = Pekarangan: Potensi Masalah $\{$ Tidak ada=1, Potensi Masalah=2

| $\mid$ PENGGUNAAN = Kantor Muhammadiyah: Potensi Masalah $\{$ Tidak ada=0, Potensi Masalah=11\}

I $\quad$ PENGGUNAAN = Kesehatan: Potensi Masalah $\{$ Tidak ada=0, Potensi Masalah=1\}

$|\quad|$ PENGGUNAAN $=$ Kos-kosan: Potensi Masalah $\{$ Tidak ada=0, Potensi Masalah=1

| $\quad$ PENGGUNAAN = Pekarangan: Potensi Masalah $\{$ Tidak ada=0, Potensi Masalah=3

| $\mid$ PENGGUNAAN = Pendidikan

| $\mid$ | STATUS TANAH = Pekarangan: Potensi Masalah $\{$ Tidak ada=2,

Potensi Masalah=9\}

| $\mid$ STATUS TANAH = Tegalan: Potensi Masalah $\{$ Tidak ada=0,

Potensi Masalah=2\}

| $\quad$ PENGGUNAAN = SOSial

| $\mid$ | STATUS TANAH = Pekarangan: Tidak ada $\{$ Tidak ada=1, Potensi Masalah=1

| $\quad$ PENGGUNAAN = Tanah Kosong: Potensi Masalah $\{$ Tidak ada=0, Potensi Masalah=10\}

| $\quad$ PENGGUNAAN = Unit Usaha

| $\mid$ STATUS TANAH = Pekarangan: Tidak ada $\{$ Tidak ada=1, Potensi Masalah=1\}

| $\quad$ PENGGUNAAN = Usaha Kos Kosan: Potensi Masalah \{Tidak ada=0, Potensi Masalah=1\}

\section{Kesimpulan}

Analisis status legalitas tanah wakaf Milik Majleis wakaf muhammadiyah jawa tengah dengan menggunakan Algoritma ID3 menghasilkan informasi kepemilikan dan status wakaf tanah yang di hasilkan dari pemodelan pohon keputusan.Penelitian ini bertujuan untuk menganalisa dan mengetahui potensi masalah dari status kepemilikan tanah wakaf .Diperoleh kesimpulan bahwa berdasarakan aturan dengan Kategori Kepemilikan untuk kategori Potensi JURNAL ILMIAH ELEKTRONIKA DAN KOMPUTER Vol. 13, No. 1, Juli $2020: 1-7$ 
masalah dan tidak ada masalah. Jumlah data yang di pakai adalah 360 .Data pelatihan yang di pakai $70 \%$ dari data yang ada dan 30\% di gunakan untuk data uji. Bersarkan hasil Pohon keputusan telah menghasilkan 26 aturan yang menunjukan adanya tanah yang berpotensi masalah dalam status kepemilikan . Rapidminner menunjukkan hasil 92,59\% akurasi sehingga informasi tersebut disimpulkan bahwa kasus hukum atau legalitas tanah yang dimiliki oleh Majelis wakaf Muhammadiyah Jawa Tengah masih mempunyai potensi yang cukup besar dan perlu mendapatkan perhatian yang serius

\section{References}

[1] M. A. Nizar, "PENGEMBANGAN WAKAF PRODUKTIF DI INDONESIA : POTENSI DAN PERMASALAHAN," 2017.

[2] M. Asy`ari, "PROBLEMATIKA TATA KELOLA WAKAF DI LINGKUNGAN MUHAMMADIYAH ACEH," J. Ilm. Islam Futur., 2017.

[3] N. F. Z. Fuadi, "Wakaf sebagai Instrumen Ekonomi Pembangunan Islam," Econ. J. Ekon. Islam, 2018.

[4] J. A. Talingdan, "Performance comparison of different classification algorithms for household poverty classification," in Proceedings - 2019 4th International Conference on Information Systems Engineering, ICISE 2019, 2019, pp. 11-15.

[5] Khin Khin Lay | San San Nwe, "Using ID3 Decision Tree Algorithm to the Student Grade Analysis and Prediction," Int. J. Trend Sci. Res. Dev. Int. J. Trend Sci. Res. Dev., vol. 3, no. 5, pp. 1392-1395, 2019.

[6] K. Kirandeep and P. N. Madan, "Deployment of ID3 decision tree algorithm for placement prediction,” Int. J. Trend Sci. Res. Dev., 2018. 